\title{
Lentinula edodes (Shiitake) Modulates Chemically Induced Mutagenesis by Enhancing Pitting
}

\author{
Patrícia L. Alves de Lima, ${ }^{1,3}$ Marina M. Sugui, ${ }^{1,3}$ Angela I.M. Petrício, ${ }^{1,3}$ \\ Lízia C. Vilela, ${ }^{2,3}$ Andréa V.F. Pinto, ${ }^{4}$ Priscila R. Martins, ${ }^{4}$ Ramon Kaneno, \\ Daniel A. Ribeiro, ${ }^{5}$ Daisy M.F. Salvadori, ${ }^{3}$ and Lúcia R. Ribeiro ${ }^{3}$ \\ ${ }^{1}$ Center for Toxicogenetic and Carcinogenic Evaluation (TOXICAN) and ${ }^{2}$ Laboratory of Immunopathology, \\ ${ }^{3}$ Department of Pathology, Faculty of Medicine; ${ }^{4}$ Department of Microbiology and Immunology, Institute of Biosciences; \\ São Paulo State University (UNESP), Botucatu, São Paulo, Brazil. \\ ${ }^{5}$ Department of Biosciences, Federal University of São Paulo (UNIFESP), São Paulo, Brazil.
}

\begin{abstract}
This study was undertaken to understand how Lentinula edodes modulates in vivo mutagenesis induced by alkylating agents in bone marrow and peripheral blood as described in our previous article. Male Swiss mice were pretreated for 15 consecutive days with aqueous extracts prepared from L. edodes, after which, the number of circulating blood cells, normal erythroid bone marrow cell cycling, and phagocytosis of micronucleated reticulocyte (MNRET) and activation of spleen macrophages were assessed. The results indicate that the antimutagenicity seen in bone marrow and peripheral blood is exerted by distinct compounds with different actions. The antimutagenic effect in bone marrow is exerted by compounds subject to degradation at deep-freeze storage temperature of $-20^{\circ} \mathrm{C}$. On the other hand, compounds responsible for antimutagenicity in peripheral blood are not subject to degradation at $-20^{\circ} \mathrm{C}$. The results also indicate that the antimutagenic action in peripheral blood leading to the reduction of circulating MNRET occurs in the spleen primarily through a phagocytic activity due to higher macrophage numbers and probably not due to the enhanced activation state of individual cells.
\end{abstract}

KEY WORDS: • culling • macrophages • micronucleus $\bullet$ pitting

\section{INTRODUCTION}

D URING THE PAST 20 years, particular attention has been directed to the study of antimutagenic compounds. Interest in these compounds also arises from the possibility of having systems that provide an accurate indication of the antimutagenic potential of a compound within a short period of time. Various compounds have been found to have antimutagenic properties, and their number continues to grow. The primary objective of the use of animal models in the antimutagenicity field is to acquire pharmacological information by taking into account absorption, distribution, metabolism, and excretion. However, although we have positive indications concerning antimutagenic properties, it is difficult to obtain a true understanding of the mechanisms involved because it is often unclear whether a specific effect is the result of a single mechanism or a combination of different mechanisms. ${ }^{1}$

Manuscript received 22 January 2013. Revision accepted 3 May 2013

Address correspondence to: Daniel A. Ribeiro, DDS, PhD, Av. Ana Costa 95, Vila Mathias Santos, São Paulo, SP 11060-001, Brazil, E-mail: daribeiro@unifesp.br
Adding more complexity to comprehending the mode of action related to the whole body approach in chemoprevention research, many complex dietary mixtures have been evaluated for their intervention in human carcinogenesis. However, extensive laboratory studies indicate that even though dietary constituents (complex mixtures) are composed of several mutagens/carcinogens as well as antimutagens/ anticarcinogens, intervention studies using specific complex food items show more effectiveness in terms of cancer reduction or increased longevity than do single compounds. ${ }^{2}$

Interest in using mushrooms and/or mushroom extracts as dietary supplements is based on theories that they enhance immune function and promote health. In fact, several reports describe the effectiveness of mushrooms against the promotion and progression stages of carcinogenesis, demonstrating that complex mixtures may have additional effects improving the prevention of cancer. ${ }^{3}$ Thus, in the same way, wholemushroom extracts containing different compounds could also interfere with the onset of mutation (initiation stage) in different ways, minimizing its potentially adverse consequences.

In 2001, our workgroup showed that an aqueous extract prepared from a fresh Lentinula edodes mushroom (LE 96/17) 
significantly reduced the induction of primary DNA damage in peripheral blood leukocytes as well as the mutagenicity induced in bone marrow and peripheral blood of mice. ${ }^{4}$ Thus, assessing some different possibilities and using the same in vivo system, this study investigated how Lentinula edodes (Berk.) Pegler [ =Lentinus edodes (Berk.) Singer] modulates the mutagenicity induced by alkylating agents in vivo as previously reported.

\section{MATERIALS AND METHODS}

Animals

Male Swiss mice aged 7-8 weeks (35-40 g body weight) were obtained from the breeding colonies of the Animal Center, UNICAMP. The animals were kept in plastic cages, in an experimental room under controlled conditions of temperature $\left(23 \pm 2^{\circ} \mathrm{C}\right)$, humidity $(50 \pm 10 \%), 12$-h light/12-h dark cycle, and ad libitum access to food and water.

\section{Chemicals}

The alkylating agents $N$-ethyl- $N$-nitrosourea (ENU; CAS No: 759-73-9; Sigma), dissolved in a phosphate buffer ( $\mathrm{pH}$ 6.0), or cyclophosphamide (CP; CAS No: 50-18-0, Genuxal; Asta Médica), dissolved in $0.9 \% \mathrm{NaCl}$, were used to induce mutations in mouse hematopoietic cells.

\section{Mushroom}

Dried powder of the L. edodes mushroom was provided by the Agronomic School of Sciences. The mushroom (strain LE 96/17), produced in 2002, was kept in plastic bags and wrapped in thick paper to provide protection from light and subsequently stored at a deep-freeze temperature of $-20^{\circ} \mathrm{C}$ until 2004. Consequently, all experiments in this study were carried out with the stored mushroom. Before storing the fresh dried powder mushroom (2002), we confirmed its antimutagenic potential $(P<.01)$ using the in vivo bone marrow micronucleus test (MNT) against ENU chemically induced mutagenesis (results not shown).

\section{Mushroom aqueous extracts}

L. edodes aqueous extract (2.5\%) was prepared using $5 \mathrm{~g}$ of powdered mushroom added to $200 \mathrm{~mL}$ of filtered water (extract 1 ), while $L$. edodes aqueous extract $2(5 \%)$ was prepared using $10 \mathrm{~g}$ of powdered mushroom added to $200 \mathrm{~mL}$. Extracts were warmed to $60^{\circ} \mathrm{C}$, and the temperature was maintained (thermometer) for $15 \mathrm{~min}$ before filtering. The filtered extract was kept in a freezer until use. After filtering, the total amount of mushroom compounds in $0.6 \mathrm{~mL}$ was about $0.015 \mathrm{~g}$ and $0.03 \mathrm{~g}$ for extracts 1 and 2, respectively. A volume of $0.6 \mathrm{~mL}$ was administered per rodent per day during the entire experimental period. The aqueous extracts used in this study were prepared from $L$. edodes powder stored for 2 years at a deep-freeze temperature of $-20^{\circ} \mathrm{C}$.

\section{Micronucleus test}

The MNT was conducted according to the methods described by MacGregor et al..$^{5}$ for bone marrow, and by
Hayashi et al. ${ }^{6}$ for peripheral blood. The number of micronucleated cells was determined by counting 1000 polychromatic erythrocytes (PCEs) and 1000 reticulocytes (RETs) per animal. Slides were scored blindly using a light microscope with a $100 \times$ immersion objective for PCEs, and a fluorescent microscope for RETs, using a combination of a blue excitation filter (e.g., $488 \mathrm{~nm})$ and a yellow to orange barrier filter (e.g., $515 \mathrm{~nm}$ long pass) and a $40 \times$ objective. The percentage of reduction in the micronucleated frequency after treatment with mushroom extracts 1 and 2 were calculated according to Manoharan and Banerjee ${ }^{7}$ and Waters et al. ${ }^{8}$

\section{Blood cell analysis}

Red blood cell counts were performed using a hematology analyzer. White blood cell counts were performed on blood smears stained with Leishmann (Merck).

\section{Phagocytic activity of spleen cells}

To determine the effects of the L. edodes mushroom on the phagocytosis of micronucleated reticulocyte (MNRET) by spleen cells, mice were pretreated with $L$. edodes extract 1 (by gavage) for 15 days before intraperitoneal (i.p.) CP $(50 \mathrm{mg} / \mathrm{kg})$ administration. Animals were subsequently sacrificed in a $\mathrm{CO}_{2}$ chamber 6 or $12 \mathrm{~h}$ after i.p. administration. Spleen cell suspensions were obtained by passing individual spleens through a stainless steel tissue sieve with a $5 \mathrm{~mL}$ cold medium (RPMI 1640; Gibco). Small cell clumps were broken down to single-cell suspensions by gentle pipetting. One hundred microliters of the single-cell suspension was placed immediately in the center of an acridine orange $(\mathrm{AO})$ precoated glass slide and covered immediately with a $24 \mathrm{~mm} \times 40 \mathrm{~mm}$ coverslip. The slides were kept in a freezer until analysis.

\section{Preparation of AO-coated glass slides}

$\mathrm{AO}$ was dissolved in distilled water at a concentration of $1 \mathrm{mg} / \mathrm{mL}$. Next, $40 \mu \mathrm{L}$ of this extract was placed on a preheated (about $70^{\circ} \mathrm{C}$ ) clean glass slide and spread with a glass rod using a back and forth motion, and the slides were then air-dried. The AO-coated glass slides were stored in a dry place at room temperature until use. ${ }^{6}$

\section{Phagocytosis analysis using fluorescent microscopy}

The combination of a blue excitation filter (e.g., $488 \mathrm{~nm})$ and a yellow to orange barrier filter (e.g., $515 \mathrm{~nm}$ long pass) should be used for microscopic analysis of slides. Before scoring, slides should be allowed to stain for a few hours overnight to allow cells to settle and to maximize staining. A suitable region of the slide should be selected with a lowpower objective before the start of phagocytosis scoring. Scored cells should be intact and the nuclei of nucleated cells were intensely fluorescent and green-labeled, while RETs are visualized in red. A total of 200 cells per animal were scored blindly and placed in two categories: absent (A) or evident (E) phagocytosis, according to Figure 1. 

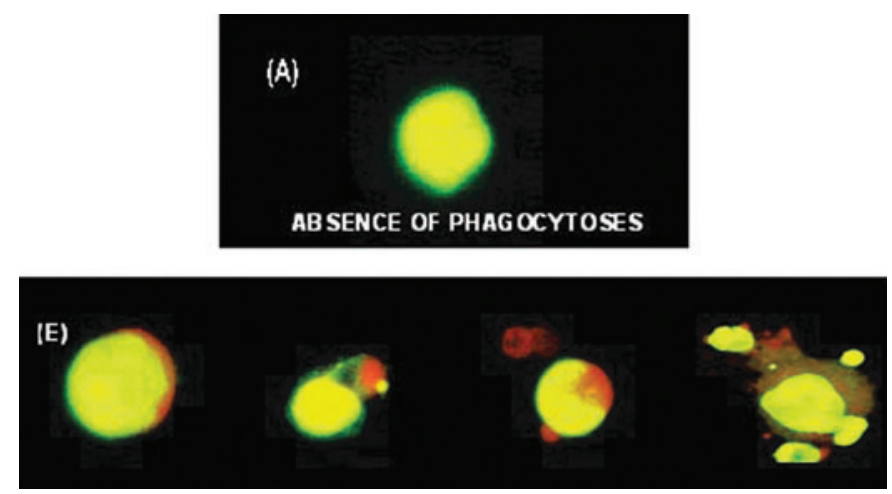

FIG. 1. Absence (A) of phagocytosis (intensely green fluorescent cell without any remnant of exogenous red color RNA). Evident (E) phagocytosis (any green fluorescent cell, which could be visualized with a minimum of exogenous RNA). Color images available online at www.liebertpub.com/jmf

\section{Assay for spontaneous release of hydrogen peroxide}

Hydrogen peroxide $\left(\mathrm{H}_{2} \mathrm{O}_{2}\right)$ release by spleen macrophages was determined according to Pick and Mizel. ${ }^{9}$ Briefly, spleen macrophages were collected as described above for determination of the phagocytic activity, and plated on 96-well flat-bottom microculture plates at a final concentration of $2 \times 10^{6}$ cells $/ \mathrm{mL}(100 \mathrm{~mL} /$ well $)$; adherent cells were grown for $24 \mathrm{~h}$ without any stimulus. The culture supernatants were removed for further nitric oxide (NO) determination, and adherent cells were used for $\mathrm{H}_{2} \mathrm{O}_{2}$ determination. The phenol red reagent $(100 \mu \mathrm{L})$ containing $140 \mathrm{mM} \mathrm{NaCl}, 10 \mathrm{mM}$ $\mathrm{K}_{2} \mathrm{HPO}_{4}, 5.5 \mathrm{mM}$ dextrose, and $5.5 \mathrm{mM}$ horseradish peroxidase was added to wells, and the adherent cells were further incubated for $1 \mathrm{~h}$ at $37^{\circ} \mathrm{C}$ in a humidified chamber $\left(5 \% \mathrm{CO}_{2}\right.$ in air). The reaction was stopped by addition of $10 \mu \mathrm{L}$ of $1 \mathrm{~N}$ $\mathrm{NaOH}$ and the absorbance was measured at $620 \mathrm{~nm}$, using an automatic enzyme immunoassay reader.

\section{Assay for spontaneous release of $\mathrm{NO}$}

NO release by spleen macrophages was determined based on the Griess reaction..$^{10}$ As described above, the supernatants of adherent cell cultures were collected after $24 \mathrm{~h}$ and mixed with $100 \mu \mathrm{L}$ of Griess reagent $(0.1 \% N$-1-naphthylethyl-enediamine $+1 \%$ sulfanilamide in $5 \% \mathrm{H}_{3} \mathrm{PO}_{4}$ ). After
10 min, absorbance was measured at $540 \mathrm{~nm}$ using an automatic enzyme immunoassay reader.

\section{Statistical methods}

The MNT data were evaluated statistically by the chisquare test. ${ }^{11}$ The numbers of hematopoietic blood cells were compared by analysis of variance on Ranks, followed by the Dunn's test using SPSS software (version 1.0) for Windows. Comparisons of $\mathrm{H}_{2} \mathrm{O}_{2}$ and $\mathrm{NO}$ production were carried out with the Kruskal-Wallis test using MINITAB software (version 14). $P$ values less than .05 were considered statistically significant.

\section{RESULTS}

\section{Influence of storage on L. edodes antimutagenic effect}

Table 1 shows the effect of $L$. edodes after 2 years of storage at deep-freeze temperature $\left(-20^{\circ} \mathrm{C}\right)$ on the frequencies of micronucleated polychromatic erythrocytes (MNPCEs) and MNRETs induced chemically by ENU $(50 \mathrm{mg} / \mathrm{kg})$, in bone marrow and in peripheral blood of mice. The results indicate that after storage, $L$. edodes extract did not reduce the frequency of bone marrow MNPCEs induced by ENU, but that the bioactive compounds responsible for the antimutagenic activity in peripheral blood caused a significant decrease in MNRET frequency. These findings indicate that antimutagenic effects seen in bone marrow and peripheral blood are exerted by compounds with different modes of action and a very different chemical stability.

\section{Influence of $\mathrm{L}$. edodes on normal cell cycling in bone marrow}

The data in Table 2 suggest that the antimutagenic effect of $L$. edodes extract are not due to an influence on normal cell cycling since there was no delay or acceleration when there was a maximum reduction in MNRET in the blood stream in the treated groups versus the positive control. The results also show that there is a statistically significant difference when both treated groups are compared to the positive control; however, a comparison between the two treated groups ( $L$. edodes extract 1 and 2 ) at the same sampling time indicated that there was no significant difference in the antimutagenic effect with dosages of 5 or

Table 1. Effects of Lentinula edodes Extracts on the Frequencies of Micronucleated Polychromatic Erythrocytes in Bone Marrow and Micronucleated Reticulocytes in Peripheral Blood After Pretreatment with $N$-Ethyl- $N$-Nitrosourea

\begin{tabular}{|c|c|c|c|c|c|c|c|}
\hline \multirow[b]{2}{*}{ Treatment } & \multirow[b]{2}{*}{ Storage } & \multirow[b]{2}{*}{$\mathrm{n}$} & \multicolumn{2}{|c|}{ MNPCES } & \multirow[b]{2}{*}{$\mathrm{n}$} & \multicolumn{2}{|c|}{ MNRETS } \\
\hline & & & No. & $\%$ & & No. & $\%$ \\
\hline Water $+0.9 \% \mathrm{NaCl}^{\mathrm{a}}$ & & 6 & 5 & 0.08 & 5 & 7 & 0.14 \\
\hline Water + ENU $(50 \mathrm{mg} / \mathrm{kg})^{\mathrm{b}}$ & & 5 & 168 & 3.36 & 6 & 149 & 2.48 \\
\hline Lentinula edodes extract $1+\mathrm{ENU}$ & 2 years $\left(-20^{\circ} \mathrm{C}\right)$ & 5 & 182 & 3.64 & 5 & 80 & $1.6 * * *$ \\
\hline
\end{tabular}

${ }^{a}$ Negative control; ${ }^{b}$ positive control.

*** Significantly different from positive control $(P<.001)$.

$\mathrm{n}$, number of animals; MNPCEs, micronucleated polychromatic erythrocytes; MNRETs, micronucleated reticulocytes; ENU, $N$-ethyl- $N$-nitrosourea. 
Table 2. Effects of Lentinula edodes Extracts on the Frequency of Micronucleated Reticulocytes in Peripheral Blood of Mice After Pretreatment with $N$-Ethyl- $N$-Nitrosourea

\begin{tabular}{|c|c|c|c|c|c|c|c|}
\hline \multirow[b]{2}{*}{ Treatment } & \multirow[b]{2}{*}{ Number of cells analyzed } & \multicolumn{2}{|c|}{ MNRETs $(24 h)$} & \multicolumn{2}{|c|}{ MNRETs (48h) } & \multicolumn{2}{|c|}{ MNRETs $(72 h)$} \\
\hline & & No. & $\%$ & No. & $\%$ & No. & $\%$ \\
\hline Water $+0.9 \% \mathrm{NaCl}^{\mathrm{a}}$ & 5000 & 7 & 0.14 & 5 & 0.1 & 7 & 0.14 \\
\hline Water + ENU $(50 \mathrm{mg} / \mathrm{kg})^{\mathrm{b}}$ & 6000 & 149 & 2.48 & 149 & 2.48 & 143 & 2.38 \\
\hline L. edodes: extract $1+$ ENU & 5000 & 80 & $1.6^{* *}$ & 77 & $1.54 * * *$ & 77 & $1.54 * *$ \\
\hline L. edodes: extract $2+\mathrm{ENU}$ & 7000 & 133 & $1.9 *$ & 113 & $1.61 * * *$ & 112 & $1.6^{* *}$ \\
\hline
\end{tabular}

${ }^{a}$ Negative control; ${ }^{b}$ positive control.

Significantly different from positive control $(* P<.05 ; * * P<.01 ; * * * P<.001)$.

Table 3. Effects of Treatment with Lentinula edodes Extracts on the Number of Blood Cells

\begin{tabular}{|c|c|c|c|c|}
\hline \multirow[b]{2}{*}{ Blood cells } & \multirow{2}{*}{$\begin{array}{c}\text { Physiological } \\
\text { values (mouse) }\end{array}$} & \multicolumn{3}{|c|}{ Treatments } \\
\hline & & Negative control (n) & L. edodes (extract 1) (n) & L. edodes (extract 2) (n) \\
\hline Lymphocytes (\%) & $55-95 \%$ & $92.1 \pm 4.1(6)$ & $90.1 \pm 4.5(6)$ & $84.8 \pm 8.04(5)$ \\
\hline Monocytes (\%) & $0.1-3.5 \%$ & $1.8 \pm 1.3(6)$ & $1.8 \pm 1.6(6)$ & $5.0 \pm 2.3 * * *(5)$ \\
\hline Neutrophiles (\%) & $10-40 \%$ & $5.8 \pm 3.7(6)$ & $8.0 \pm 4.7(6)$ & $10.0 \pm 6.4(5)$ \\
\hline Basophiles (\%) & $0-0.3 \%$ & - & - & - \\
\hline Eosinophiles $(\%)$ & $0-0.4 \%$ & $1.0 \pm 0(6)$ & - & - \\
\hline Red blood cells $\left(\times 10^{6} / \mathrm{mm}^{3}\right)$ & $7-12.5 \times 10^{6} / \mathrm{mm}^{3}$ & $8.6 \pm 0.5(9)$ & $8.9 \pm 1.1(5)$ & $8.3 \pm 1.2(5)$ \\
\hline
\end{tabular}

***:Significantly different from positive control $(P<.001)$.

$10 \mathrm{mg} /$ day. Another important observation in Table 2 is that the reduction in MNRET frequency takes place by the first sampling time, indicating that the antimutagenic action occurs rapidly within the first $24 \mathrm{~h}$ after ENU administration.

\section{Effect of L. edodes on the number of circulating blood cells}

Table 3 presents the effect of treatment with $L$. edodes extracts on the number of circulating blood cells. The results indicate that the number of red blood cells determined in the treated group was not statistically different from that of the nontreated rodents. However, there was a significant increase in the relative number of monocytes observed in the blood smears. We also observed a biological effect related to the relative number of neutrophiles, although not statistically significant.

\section{Effect of $\mathrm{L}$. edodes on phagocytosis of MNRET}

Table 4 shows the effect of $L$. edodes extract 1 on the frequency of spleen cell phagocytosis in mice. A comparison between the positive control and treated group clearly indicates that the antimutagenic effect of $L$. edodes toward MNRET in peripheral blood was due in large part to the increased spleen cell phagocytosis of MNRET, which was equally significant at 6 and $12 \mathrm{~h}(P<.001)$ after micronucleus induction with $\mathrm{CP}$.

Effect of $\mathrm{L}$. edodes on the activation of spleen macrophages

Figures 2 and 3 show that even though the spleen phagocytic activity was greatly increased by $L$. edodes pretreatment, the production of $\mathrm{H}_{2} \mathrm{O}_{2}$ and $\mathrm{NO}$ from macrophages was comparable to the control value.

\section{DISCUSSION}

In our previous article, ${ }^{4}$ we reported that an aqueous extract obtained at $60^{\circ} \mathrm{C}$ from L. edodes fruiting bodies (strain 96/17) modulates the mutagenic effect induced chemically by $\mathrm{CP}$ and ENU in bone marrow PCEs as well as in peripheral blood RETs. That study also gave us an indication of one of the possible antimutagenic actions. The use of the comet assay with peripheral blood leukocytes indicated that

Table 4. Effects of Lentinula edodes Extract 1 ON the Frequency of Splenic Phagocytosis in Mice 6 or 12 h After Pretreatment With Cyclophosphamide (50 MG/KG)

\begin{tabular}{|c|c|c|c|}
\hline Treatment & $n$ & $\begin{array}{c}\text { Number of } \\
\text { cells analyzed }\end{array}$ & $\begin{array}{c}\text { Number of cells } \\
\text { with evident } \\
\text { phagocytic activity }\end{array}$ \\
\hline \multicolumn{4}{|l|}{$6 \mathrm{~h}$ after $\mathrm{CP}$ i.p. } \\
\hline Water + CP $(50 \mathrm{mg} / \mathrm{kg})^{\mathrm{a}}$ & 4 & 800 & $158(19.75 \%)$ \\
\hline $\begin{array}{l}\text { L. edodes: extract } \\
1+\mathrm{CP}(50 \mathrm{mg} / \mathrm{kg})\end{array}$ & 5 & 1000 & $373 * * *(37.3 \%)$ \\
\hline \multicolumn{4}{|l|}{$12 \mathrm{~h}$ after $\mathrm{CP}$ i.p. } \\
\hline Water + CP $(50 \mathrm{mg} / \mathrm{kg})^{\mathrm{a}}$ & 3 & 600 & $108(18 \%)$ \\
\hline $\begin{array}{l}\text { L. edodes: extract } \\
1+\mathrm{CP}(50 \mathrm{mg} / \mathrm{kg})\end{array}$ & 5 & 1000 & $370 * * *(37 \%)$ \\
\hline
\end{tabular}

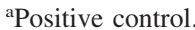

$* * *$ Significantly different from positive control $(P<.001)$.

$\mathrm{CP}$, cyclophosphamide; i.p., intraperitoneally. 


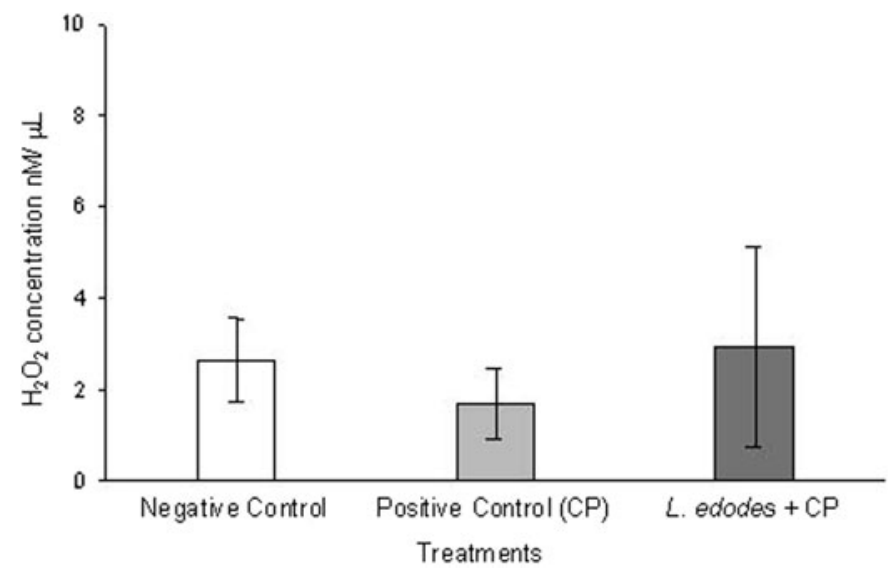

FIG. 2. $\mathrm{H}_{2} \mathrm{O}_{2}$ splenic macrophage concentrations $(\mathrm{nM} / \mu \mathrm{L})$ from mice pretreated with Lentinula edodes extract 1.

pretreatment with $L$. edodes significantly diminished the primary DNA damage induced by ENU. Consequently, it is possible that a general protection related to this reduction in DNA damage could also have affected bone marrow proerythroblasts contributing to a decrease in the frequency of MNPCE and MNRET in the treated groups.

In 2002, we received a new batch of (LE 96/17) to extend our investigation of the mode of action of the antimutagenic effect exerted by L. edodes extract. An evaluation carried out in the same year together with a subsequent one performed after 2 years of storage at $-20^{\circ} \mathrm{C}$ gave us a second indication of active compound(s) acting at very distinguishable levels (Table 1). Interestingly, while the antimutagenic effect in bone marrow was completely abolished during storage, the antimutagenicity seen in peripheral blood was maintained with high statistical significance (Tables 1 and 2), indicating that the antimutagenic effects in bone marrow and peripheral blood are exerted by different active compounds differing in mode of action and exhibiting a very different chemical stability. The result also shows that the aqueous extracts have several bioactive compounds

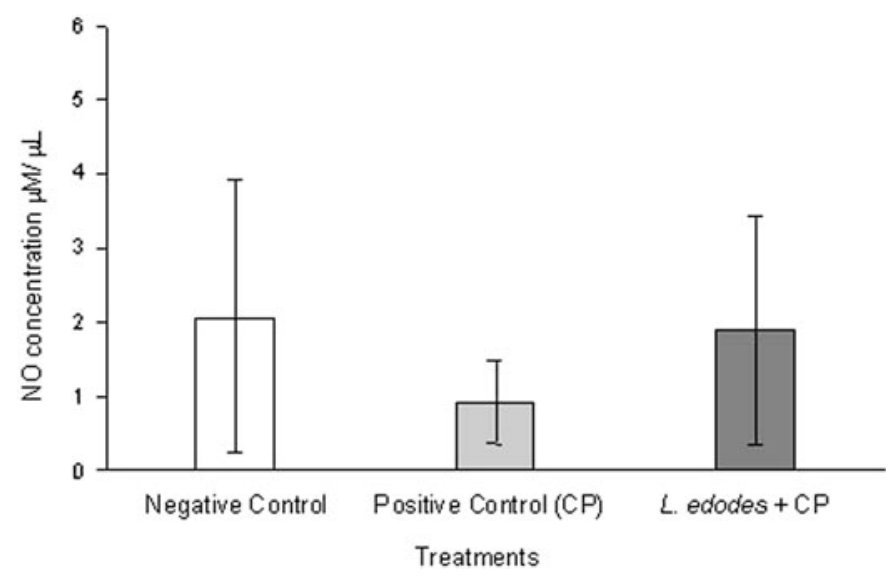

FIG. 3. Nitric oxide splenic macrophage concentrations $(\mu \mathrm{m} / \mu \mathrm{L})$ from mice pretreated with Lentinula edodes extract 1. acting together at different levels to reduce the induced mutagenesis. Several studies have postulated that the stability factor plays a critical role for exerting biological actions. ${ }^{12,13}$

The MNT in peripheral blood can be conducted without sacrificing the animals. Therefore, an investigation of potential cell cycling alterations is possible by monitoring for several days after exposure to a clastogenic agent (Table 2). The results showed that the antimutagenic effect of L. edodes in blood is not due to an influence on normal cell cycling of the erythroid lineage in bone marrow since there was no delay or acceleration related to the maximum response of MNRET in the blood stream in treated groups when compared to the positive control. A comparison between groups treated with dosages of 5 or $10 \mathrm{mg} /$ day showed that an increase in the L. edodes dose did not cause any significant impact on antimutagenicity (Table 2), indicating that the optimum dose is achieved at $\leq 5 \mathrm{mg}$ /day, with higher concentrations of the bioactive compounds $(10 \mathrm{mg} /$ day) having no additional effect on MNRET.

We also investigated the general numbers of circulating hematopoietic cells based on the possibility that $L$. edodes treatment modulates the number of circulating red blood cells, causing a relative increase in blood stream RETs, which could give the impression of a reduction in MNRET (Table 3). In general, our results indicated that the number of hematopoietic red blood cells determined in treated groups was not statistically different from nontreated rodents. However, there was a significant increase in the relative number of monocytes observed in blood smears. Our data are in accord with a previous report that lentinan, a polysaccharide obtained from $L$. edodes, increases monocytes in peripheral blood as well as granulocyte progenitor (colonyforming unit-granulocyte macrophage [CFU-GM]) cells in the spleen and bone marrow. ${ }^{14}$ Since some of the actions exerted by this isolated polysaccharide have also been found in experiments using L. edodes fruiting bodies, ${ }^{15,16}$ we suppose that the aqueous extract used in this study could have acted in a manner similar to that of lentinan, increasing blood stream monocytes and possibly granulocyte progenitors (CFU-GMs). In fact, although we do not know the chemical composition of $L$. edodes aqueous extract, it had been demonstrated that aqueous extracts of several mushrooms contain a high concentration of polysaccharides, which could be responsible for the bioactive effects. ${ }^{17-19}$

Monocytes have an intravascular life span of 1-3 days, leaving the blood stream at random and transforming into macrophages. Macrophages are phagocytes and function to remove foreign bodies, parasites, and bacteria. ${ }^{20}$ Thus, if we look at the results in Table 3 from this perspective, we could suppose that the reduction in MNRETs in peripheral blood can be due to the enhanced phagocytic activity in the spleen. Blood filtration is the best known and a very important function of the spleen. Elements removed from circulation include aging cells and intraerythrocytic inclusions. The removal of aging or abnormal red blood cells by the spleen occurs within the cords of Billroth and is known as culling, ${ }^{21,22}$ whose molecular mechanism is still under investigation. 
However, it is generally agreed that cells bound for destruction become trapped, or perhaps held, within the reticulum meshwork of the spleen cords, and as their splenic transit time increases, they succumb to phagocytosis by resident macrophages. In addition to culling, the spleen also functions to remove intraerythrocytic inclusions (micronucleus and intraerythrocytic parasites such as Plasmodium falciparum) from circulating red cells. The ability of the spleen to clear these inclusions, while maintaining the integrity of the red cell itself is known as pitting and is an exclusive function of splenic tissue. Pitting occurs as cells within the cords attempt to reenter the circulation through the splenic sinuses. To do this, they must pass through slit-like fenestrations of the sinus endothelium. As this occurs, the deformable portion of the cell bends to negotiate the opening, whereas the inclusion, which is nondeformable, is unable to pass through the narrow passage; thus, it is left behind to be phagocytized by resident macrophages. $^{23-25}$

The above considerations led us to adapt the protocol developed by Hayashi et al. ${ }^{6}$ to measure the spleen phagocytic activity. Our results support the view that the antimutagenic action toward MNRET in peripheral blood can be modulated largely by the splenic phagocytic activity (Table $4)$, which is equally increased with $L$. edodes treatment both at 6 and $12 \mathrm{~h}(P<.001)$ after micronucleus induction by $\mathrm{CP}$. This intense activity in the first $12 \mathrm{~h}$ explains why the reduction in the frequency of MNRET was almost maximum $24 \mathrm{~h}$ after the induction of mutations (Table 2). Figures 2 and 3 show that even though the spleen phagocytic activity was greatly increased by $L$. edodes treatment, the production of $\mathrm{H}_{2} \mathrm{O}_{2}$ and $\mathrm{NO}$ from macrophages of mice treated with L. edodes extract was comparable to the control values. Thus, the results suggest that the increased clearance function of the spleen was probably due to the higher number of macrophages and not due to the enhanced activation state of individual cells.

The understanding that $L$. edodes blood antimutagenicity related to reduction in MNRET was produced by specific enhancement of spleen phagocytosis helps to amplify the overall picture and suggests that this specific action could be better evaluated by using different experimental models to determine whether it could be applied in some way, for example, as an adjuvant or in a prophylactic manner to reduce the body parasite burden in infectious diseases involving intraerythrocytic parasites, such as in malaria. However, further studies are necessary before $L$. edodes can be used in the prophylaxis treatment of infectious parasitic diseases, which are very frequent in developing countries such as Brazil.

Finally, this study points out that clarifying the mode of actions of $L$. edodes using in vivo models to elucidate the underlying events of the observed effect is important since it can unexpectedly open up practical applications in different areas.

\section{ACKNOWLEDGMENTS}

This study was supported by grants from Fundação de Amparo à Pesquisa do Estado de São Paulo (FAPESP),
Brazil. We also thank Dr. A. Leyva for English language editing of the manuscript.

\section{AUTHOR DISCLOSURE STATEMENT}

No competing financial interests exist.

\section{REFERENCES}

1. Bronzetti G, Crose CD, Aretini P, Fiorio R: Antimutagenesis and anticancer effects. J Environ Pathol Toxicol Oncol 1996;15: 59-64.

2. DeMarine DM: Dietary interventions of human carcinogenesis. Mutat Res 1998;400:457-465.

3. Borchers AT, Keen CL, Gershwin M: Mushrooms, tumors, and immunity, an update. Proc Soc Exp Biol Med 2004;32:393-405.

4. Alves de Lima PL, Delmanto RD, Sugui MM, et al.: Lentinula edodes (Berk.) Pegler (Shiitake) modulates genotoxic and mutagenic effects induced by alkylating agents in vivo. Mutat Res 2001;496:23-32.

5. MacGregor JT, Heddle JA, Hite M, et al.: Guidelines for the conduct of micronucleus assay in mammalian bone marrow erythrocytes. Mutat Res 1987;189:103-112.

6. Hayashi M, Morita I, Kodama Y, Sofuni T, Ishidate JRM: The micronucleus assay with mouse peripheral blood reticulocytes using acridine orange-coated slides. Mutat Res 1990;245:245-249.

7. Manoharan K, Banerjee MR: $\beta$-Carotene reduces sister chromatid exchange induced by carcinogens in mouse mammary cells in organ culture. Cell Biol Int Rep 1985;9:783-789.

8. Waters MD, Brady AL, Stack HF, Brookman HE: Antimutagenic profiles for some model compounds. Mutat Res 1990;238:57-85.

9. Pick A, Mizel A: A rapid microassay of the measurements of superoxide and hydrogen peroxide production by macrophages in culture using automatic enzyme immunoassay reader. J Immunol 1981;46:2111-2126.

10. Green LC: Nitrite biosynthesis in man. Proc Natl Acad Sci USA 1981;18:7764-7768.

11. Pereira CAB: Teste estatístico para comparar proporções em problemas de citogenética. In: Mutagênese, Teratogênese $e$ Carcinogênese (Rabello-Gay MN, Rodrigues MALR, Montelleone-Neto, eds.). Métodos e Critérios de Avaliação, FCA, São Paulo, Brazil, 1991, pp. 113-121.

12. Tichý E, Vitková Z, Cupková B: Effect of beta-(1,3)-glucan on rheological properties and stability of topical formulations. Pharmazie 2006;61:1050-1051.

13. Murcia MA, Martínez-Tomé M, Jiménez AM, Vera AM, Honrubia M, Parras P: Antioxidant activity of edible fungi (truffles and mushrooms): losses during industrial processing. J Food Prot 2002;65:1614-1622.

14. Matsuo T, Kurahashi Y, Nishida S, Kumada K, Hayami T, Takagi T: Granulopoietic effects of lentinan in mice, effects on GM-CFC and 5-FU-induced leucopenia. Jpn J Cancer Chemother 1987;14:1310.

15. Nanba H, Kuroda H: Antitumor mechanisms of orally administered shiitake fruit bodies. Chem Pharm Bull 1987;35:2459-2464.

16. Nanba H, Mori K, Toyomasu T, Kuroda H: Antitumor action of shiitake (Lentinus edodes) fruit bodies orally administered to mice. Chem Pharm Bull 1987;35:2453-2458.

17. Chu KKW, Ho SSS, Chow AHL: Coriolus versicolor, a medicinal mushroom with promising immunotherapeutic values. J Clin Pharmacol 2002;42:976-984. 
18. Ikegawa T, Saitoh H, Feng W, Zhang H, Li L, Matsuzawa T: Antitumor activity of Hypsizigus marmoreus. I. Anti-tumor activity of extracts and polysaccharides. Chem Pharm Bull 1992;40:1954-1957.

19. Pramanik M, Mondal S, Chakraborty I, Rout D, Islam SS: Structural investigation of polysaccharide (Fr.II) isolated from the aqueous extract of an edible mushroom, Pleurotus sajor-caju. Carbohydr Res 2005;340:629-636.

20. Irons RD: Blood and bone marrow. In: Handbook of Toxicology Pathology (Haschek W, Rousseaux C, eds.). Academic Press, New York, 1991, pp. 389-404.

21. Goodman J, Martin IN, William CC: Disorders of the spleen. In: Wintrobe's Clinical Hematology (Greer JP, Foerster J, Lukens JN, Rodgers GM, Paraskevas F, Glader B, eds.). Lippincott Williams and Wilkins, Philadelphia, PA, USA, 2004, pp. 894-909.
22. Kashimura M, Fujita T: A scanning electron microscopy study of human spleen, relationship between the microcirculation and functions. Scanning Microsc 1987;1:841-851.

23. Pabst R, Westermann J, Rothkötter HJ: Immunoarchitecture of regenerated splenic and lymph node transplants. Int Rev Cytol 1991;128:215-260.

24. Schwartz SI. Physiology of the spleen and the role of splenectomy in hematological disorders. In: Surgical Critical Care II (Condon RE, DeCrosse J, eds.). Lea \& Febiger, Philadelphia, PA, USA, 1985, pp. 118-125.

25. Weiss L: Mechanisms of splenic clearance of the blood; a structural overview of the mammalian spleen. In: The Spleen (Bowdler AJ, ed.). Chapman and Hall Medical, London, 1995, pp. 23-44. 